\title{
Journal of the Royal Asiatic Society
}

http://journals.cambridge.org/JRA

Additional services for Journal of the Royal Asiatic Society:

Email alerts: $\underline{\text { Click here }}$ Subscriptions: Click here Commercial reprints: Click here Terms of use : $\underline{\text { Click here }}$

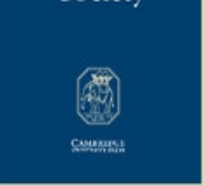

\section{Art. III.-A Collection of Kammavācās}

Herbert Baynes

Journal of the Royal Asiatic Society / Volume 24 / Issue 01 / January 1892, pp $53-75$

DOI: 10.1017/S0035869X00021511, Published online: 15 March 2011

Link to this article: http://journals.cambridge.org/ abstract S0035869X00021511

How to cite this article:

Herbert Baynes (1892). Art. III._A Collection of Kammavācās. Journal of the Royal Asiatic Society, 24, pp 53-75 doi:10.1017/ S0035869X00021511

Request Permissions : $\underline{\text { Click here }}$ 
Art. III.-A Collection of Kammaväcäs. By Herbert BAYNes, M.R.A.S.

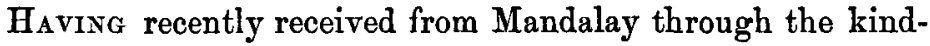
ness of an uncle, several interesting and important Buddhist MSS. in Pāli, Burmese and Shan, I venture to lay before the Society a Collection of Kammavācās, some of which, though known to European scholars, have hitherto remained inedited.

The first Manuscript is a very handsome copy of the Kammavācam in Burmese Ritual, or 'tamarind-seed' letters painted with a thick black resinous gum on 16 leaves of royal discarded pasohs, each leaf containing 6 lines each side.

It begins with the Upasampada or Buddhist Ordination Service, which is perhaps the best known of all the Kammavâcās, having been edited by Spiegel in 184l, by Dickson in 1881, and by Frankfurter in 1883. Then follow eight others, namely :-

2. Kathinadussam uppannam, 'the Bestowment of the Kațina Robe.'

3. Ticivarena avippavāsa, 'the Investiture of a Bhikkhu with the three Robes.'

4. Sìmā - sammannitā samāna - samvāsā ekuposathā, 'the fixing of a Boundary for the Performance of the Uposathā.'

5. Thera-Sammuti, ' the Election of an Elder.'

6. Nāma-Sammuti, 'naming a Bhikkhu.'

7. Vihāra-kappiyabhūmi-Sammuti, 'the Dedication of a Vihāra.'

8. Kutivatthu - Sammuti, ' fixing a Site for a Bhikkhu's Residence.'

9. Nissaya-mutta-Sammuti, 'Consent to a Release from Nissaya.' 
The first seven are given by Dr. Frankfurter in his Handbook of Păli, but whilst in his MS. the Bestowment of the Kathina Robe comes fourth in the series, in mine it occupies the second place. So far as I know, the eighth and ninth Kammavācās have never been published. They are as follows:-

\section{VIII.}

Suṇātu me bhante Sạ̣gho. Ayam itthannāmo bhikkhu samyācikāya kuṭi kattukāmo assāmikam attuddesạ̣. So samgham kuṭivatthum olokanam yācati. Yadi samghassa pattakallạ̣ sạ̣gho itthannāmañ ca itthannāmañ ca bhikkhū sammanneyya itthannāmassa bhikkhuno kuṭivatthum oloketự. Esā ñatti.

Suṇātu me bhante samgho. Ayam itthannāmo bhikkhu saṃyācikāya kuṭi kattukāmo assămikaṃ attuddesam. So samghạ̣ kuṭivatthuṃ olokanaṃ yācati. Samgho itthannāmañ ca itthannāmañ ca bhikkhụ̣ sammannati itthannāmassa bhikkhuno kuṭivatthum oloketum. Yassāyasmato khamati itthannāmassa ca itthannāmassa ca bhikkhūnam sammuti itthannāmassa bhikkhuno kuṭivatthum oloketum so tụ̣hassa, yassa nakkhamati, so bhāseyya.

Sammannitā samghena itthannāmo ca ithannāmo ca bhikkhū itthannāmassa bhikkhuno kuṭivatthụ̣ oloketum. Khamati sạ̣ghassa tasmā tuṇhī evam etạ̣ dhārayāmîti.

Let the Venerable Assembly hear me! A certain Bhikkhu, at his own instance, is about to build a house, not by the direction of others, for himself to live in. So he asks the Samgha to inspect the site. If it seem meet to the Samgha, let it appoint such and such Bhikkhus to inspect the site of the house with the said Bhikkhu. This is the motion.

Venerable Sirs, let the Brotherhood hear me! A certain Bhikkhu, at his own instance, and not by the direction of others, is about to build a house to live in. So he asks the Samgha to inspect the site. The Samgha appoints such and such Bhikkhus to inspect the site for the house with the said Bhikkhu. 
Whosoever is in favour of appointing such and such of the Bhikkhus to inspect the site with the said Bhikkhu, let him be silent; whosoever does not approve, let him speak.

Such and such Bhikkhus have been elected by the Samgha to inspect the site of the house with the said Bhikkhu. By its silence the Samgha approves ; thus I understand it.

In connexion with this Act of the Buddhist Chapter it is well to remember the following instructions given in the Pātimokkha (iv. 6) :-

Saṃyācikāya pana bhikkhunā kuṭị̣ kārayamānena assāmikạ̣ attuddesạ̣ pamāṇikā kāretabbā. Tatr' idạ̣ pamānạ̣, dīghaso dvādasa vidatthiyo sugatavidatthiyā, tiriyam sattantarā, bhikkhū abhinetabbā vatthudesanāya, tehi bhikkhūhi vatthum desetabbạ̣ anārambhạ̣ saparikkamanaṃ. Sārambhe ce bhikkhu vatthusmị̣ aparikkamane samyācikāya kuṭim kareyya, bhikkhū vā anabhineyya vatthudesanāya, pamānạ̣ vā atikkameyya, saṃghādiseso.

If any Bhikkhu, at his own instance, and not by the direction of others, should get a house built for himself to live in, he must have it built of the following dimensions. The length twelve spans of the span of Buddha, the breadth inside seven such spans. He must assemble the priests to lay out the site. 'The site must be laid out by them so as to do no damage [i.e. so as not to destroy white ants' nests or the abodes of other living things], and so as to have a clear space round it sufficient for a cart drawn by a yoke of oxen to pass. If any Bhikkhu, at his own instance, gets a house built on a site where life will be destroyed, and which has not sufficient space around, or if he fails to assemble the Bhikkbus to lay out the site, or if he exceed the limits (named above), he is guilty of an offence involving temporary separation from the Brotherhood.

\section{IX.}

Aham bhante nissayamutta-sammutim icchāmi. So 'hạ̣ bhante samgham nissayamutta-sammutị̣ yācāmîti. [Dutiyam pi, tatiyam pi yācitabbo.] 
Suṇatu me bhante samgho. Yadi samghassa pattakallạ̣ sạ̣gho itthannāmam bhikkhum nissayamutta-sammutị̣ sammanneyya. Esā ñatti.

Suṇātū me bhante sạ̣gho. Saṃgho itthannāmam bhikkhụ̣ nissayamutta-sammutim sammannati. Yassāyasmato khamati itthannāmassa bhikkhuno nissayamutta-sammuti so tuṇhassa, yassa na kkhamati so bhāseyya.

Sammatā saṃghena itthannāmassa bhikkhuno nissayamutta-sammuti. Khamati saṃghassa tasmā tụ̣hī, evam etạ̣ dhārayāmîti.

Being desirous, Venerable Sirs, of your consent to a release from Nissaya, I hereby ask the Samgha, formally, for such release. [This should be asked a second and a third time.]

Venerable Sirs, may the Brotherhood hear me! If it seem meet to the Samgha, let it consent to the said Bhikkhu's being released from Nissaya. This is the motion.

Let the Venerable Assembly hear me! The Samgha consents to the said Bhikkhu's release from Nissaya. Whosoever is in favour of the motion, let him be silent; whosoever does not approve, let him speak.

Release has been granted to the said Bhikkhu by the Samgha. By its silence the Samgha approves; thus I understand.

The second MS. consists of 58 Talipat leaves of 5 lines in characters which are midway between Burmese and Kambodian. Like the first it begins with the Upasampada. Then comes what may be called the Act of the Chapter with regard to Bhikkhus who have committed offences involving temporary separation from the Fraternity. We have, in fact, to deal with those questions of Probation, Penance and Rehabilitation which are discussed in the first three Khandhakas of the Cullavagga. 


\section{Suddhantaparivāsa.}

Aham bhante sambahulā saṃghādisesā āpattiyo āpajjị̣. Āpattipariyantạ̣ na jānāmi, rattipariyantạ̣ na jānāmi. Āpattipariyantạ̣ na sarāmi, rattipariyantạ̣ na sarāmi. Āpattipariyante vematiko, rattipariyante vematiko. So 'hạ̣ bhante samgham tāsạ̣ āpattīnạ̣ suddhantaparivāsam yācāmi.

Suṇātu me bhante saṃgho. Ayạ̣ itthannāmo bhikkhu sambahulā samghādisesā āpattiyo āpajji. Āpattipariyantạ̣ na jānāti, rattipariyantạ na jānāti. Āpattipariyantạ̣ na sarati, rattipariyantam na sarati. Āpattipariyante vematiko, rattipariyante vematiko. So saṃgham täsạ̣ āpattinaṃ suddhantaparivāsạ̣ yācati. Yadi saṃghassa pattakallạ̣ sạ̣gho itthannāmassa bhikkhuno tāsaṃāpattīnaṃ suddhantaparivāsam dadeyya.

\section{Esā natti.}

Suṇātu me bhante saṃgho. Ayam itthannāmo bhikkhu sambahulā saṃghādisesā āpattiyo āpajji. Āpattipariyantạ̣ na jānāti, rattipariyantạ̣ na jānāti. Āpattipariyantạ na sarati, rattipariyantam na sarati. Āpattipariyante vematiko, rattipariyante vematiko. So saṃgham tāsaṃ āpattīnaṃ suddhantaparivāsaṃ yācati. Samgho itthannāmassa bhikkhuno tāsạ̣ āpattīnạ̣ suddhantaparivāsạ̣ dēti. Yassāyasmato khamati itthannāmassa bhikkhuno tāsaṇ āpattīnạ̣ suddhantaparivāsassa dānam,, so tụ̣hassa. Dutiyam pi, tatiyam pi etam attham vadāmi.

Suṇātu me bhante sạ̣gho. Ayam itthannāmo bhikkhu sambahulā sạ̣ghādisesā āpattiyo āpajji. Āpattipariyantạ̣ na jānāti, rattipariyantạ̣ na jānāti. Āpattipariyantạ na sarati, rattipariyantam na sarati. Āpattipariyante vematiko, rattipariyante vematiko. So samgham tāsam āpattīnam suddhantaparivāsam yācati. Samgho itthannāmassa bhikkhuno tāsam āpattīnam suddhantaparivāsam dẹti. Yassāyasmato khamati itthannāmassa bhikkhuno tāsam āpattīnạ̣ suddhantaparivāsassa dāuam, so tuṇhassa, yassa na kkhamati, so bhāseyya. Tatiyam pi etam atthạ̣ vadāmi.

Suṇātu me bhante sạ̣gho. Ayạ̣ itthannāmo bhikkhu 
sambahulā saṃghādisesā āpattiyo āpajji. Āpattipariyantạ̣ na jānāti, rattipariyantạ̣ na jānāti. Āpattipariyantạn na sarati, rattipariyantạ na sarati. $\bar{A}$ pattipariyante vematiko, rattiparyante vematiko. So saṃghạ̣ tāsam āpattinam suddhantaparivāsaṃ yācati. Saṃgho itthannāmassa bhikkhuno tāsam āpattīnam suddhantaparivāsam deti. Yassāyasmato khamati itthannāmassa bhikkhuno tāsam āpattīnạ̣ suddhantaparivāsassa dānam, so tụ̣hassa, yassa na kkhamati, so bhāseyya. Dinno samghena itthannāmassa bhikkhuno tāsaṃ āpattīnạ̣ suddhantaparivāso. Khamati saṃghassa tasmā tuṇhī evam etạ̣ dhārayāmi. Parìvāsạ̣ sammādiyāmi. Vattạ̣ sammāìyāmi.

Aham bhante sambahulā sạ̣ghādisesā āpattiyo āpajjiṃ. Āpattipariyantạ̣ na jānāmi, rattipariyantạ na jānāmi. Āpattipariyantạ̣ na sarāmi, rattipariyantạ̣ na sarāmi. Äpattipariyante vematiko, rattipariyante vematiko. So 'ham bhante sạ̣ghạ̣ tāsạ̣ āpattīnạ̣ suddhantaparivāsạ̣ yāciṃ, tassa me saṃgho tāsạ̣ āpattinaṃ suddhantaparivāsạ̣ adāsi. So 'hạ̣ bhante parivāsassāmi evadiyām' ahạ̣ bhante evadiyatîti mạ̣ sạ̣gho dhāretu. Vattạ nikkhippāmi. Parivāsạ̣ nikkhippāmi.

Parivāsaṃ samatam nițțitạ̣.

\section{Probation of Complete Purification.}

Venerable Sirs, I have been guilty of many Samghādisesa offences, but $I$ am not aware of the degree of the offences and am unaware of the duration of the times. I do not remember the degree of the offences, nor do I remember the duration of the times. I am uncertain as to the degree of the offences and as to the duration of the times. So I ask the Venerable Assembly for a probation of complete purification on account of these offences.

Let the Venerable Fraternity hear me! A certain Bhikkhu has committed numerous offences involving temporary separation from the Brotherhood, but he is not aware of the degree of the offences and is unaware of the duration of the times. He does not remember either the one or 
the other, and is, in fact, uncertain as to both. So he asks the Samgha for a probation of Complete Purification on account of these offences. If it seem meet to the Samgha, let it impose upon the said Bhikkhu a probation of Complete Purification on account of these offences.

This is the motion.

Venerable Sirs, may the Samgha hear me! A certain Bhikkhu has committed numerous Samghādisesa offences, but he knows neither the degrees of the offences nor the duration of the times. He neither remembers the degree nor the duration of the times of such offences, and is, in fact, uncertain as to both. So he asks the Samgha to impose upon him a probation of Complete Purification in respect of these offences. The Samgha accordingly imposes upon this Bhikkhu such probation. Whosoever is in favour of the motion, let him be silent. I say the same thing twice, nay, thrice.

Let the venerable Assembly hear me! A certain Bhikkhu has been guilty of many Samghādisesa offences, but he knows neither the degree of the offences nor the duration of the times. Of such offences he cannot call to mind either the degree or the duration of the times, and is, in fact, uncertain as to both. So he asks the Samgha for a probation of Complete Purification on account of such offences. Accordingly the Samgha imposes upon him such probation. Whosoever is in favour of the motion, let him be silent; whoso does not approve, let him speak! I say the same thing thrice.

Venerable Sirs, let the Brotherhood hear me! A certain Bhikkhu has been guilty of several offences involving temporary separation from the Samgha, but he is ignorant alike of the degree of the offences and of the duration of the times. $\mathrm{He}$ does not recollect either, and is, indeed, uncertain as to both. So he asks the Samgha for a probation of Complete Purification on account of these offences. And the Samgha accordingly imposes such probation upon this Bhikkhu. Whosoever is in favour of granting to this Bhikkhu a probation of complete purification on account 
of these offences, let him be silent; whoever does not approve, let him speak! A probation of Complete Purification has been imposed by the Samgha upon this Bhikkhu on account of these offences. By its silence the Samgha approves; thus I understand it. I appreciate the probation, yea, I appreciate it in its fulness !

Venerable Sirs, I have committed numerous Samghādisesa offences, but I am ignorant alike of the degree of the offences and of the duration of the times. I recollect neither, and am, indeed, uncertain as to both. So I asked the Samgha for a probation of Complete Purification on account of these offences, and the venerable Assembly granted me such probation. Having been thus pit under probation, let the Samgha understand that I will carry it through to the end. I keep the probation, yea, I keep it.

The complete Probation is ended.

\section{Chärattam Mãnattam.}

Aham bhante sambahulā sạ̣ghādisesā āpattiyo āpajjim. Āpattipariyantạ̣ na jānāmi, rattipariyantạ̣ na jānāmi. Ápattipariyantạ̣ na sarāmi, rattipariyantạ̣ na sarāmi. Āpattipariyante vematiko, rattipariyante vematiko. So 'ham bhante saṃghạ tāsam āpattīnam suddhantaparivāsam yācim, tassa me saṃgho tāsam ạpattīnam suddhantaparivāsam ad̄āsi. So parivutthaparivāso aham bhante sambahulā samghādisesā āpattiyo āpajjị̣. A pațicchannāyo. So 'hạ̣ bhante samghhạ tāsam sambahulānam ạ àpattinam pațicchannānañ ca, apațicchannānañ ca, chārattạ mānattạ yācāmi.

Suñātu me bhante samgho. Ayam itthannāmo bhikkhu sambahulā samghādisesā āpattiyo āpajji. Āpattipariyantam na jānāti, rattipariyantam na jānāti. Āpattipariyantam na sarati, rattipariyantam na sarati. $\bar{A}$ pattipariyante vematiko, rattipariyante vematiko. So samgham tāsam ạpattīnam suddhantaparivāsam yāci. Samgho itthannāmussa bhikkhuno tāsaṃ āpattīnam suddhantaparivāsam adāsi. So parivutthaparivāso ayạ̣ itthannāmo bhikkhu sambahulā saṃghādisesā 
āpattiyo āpajji. Apaṭicchannāyo. So saṃghạ̣ tāsạ̣ sambahulānam āpattīnạ̣ paticchannānañ ca, apaṭicchannānañ ca, chārattạ̣ mānattạ̣ yācati. Yadi saṃghassa pattakallạ̣, saṃgho itthannāmassa bhikkhuno tāsaṃ sambahulānạ̣ āpattīnam paticchannānañ ca, apaṭicchannānañ ca, chārattạ̣ mānattạ̣ dadeyya.

Esā ñatti.

Suṇātu me bhante saṃgho. Ayam itthannāmo bhikkhu sambahulā samghādisesā āpattiyo āpajji. Āpattipariyantam na jānāti, rattipariyantạ̣ na jānāti. Āpattipariyantạ̣ na sarati, rattipariyantam na sarati. Āpattipariyante vematiko, rattipariyante vematiko. So sạ̣ghạ̣ tāsạ̣ āpattinaṃ suddhantaparivāsam yāci. Samgho itthannāmassa bhikkhuno tāsam āpattīnam suddhantaparivāsaṃ adāsi. So parivutthaparivāso ayam itthannāmo bhikkhu sambahulā samghādisesā āpattiyo āpajji. Apaṭicchannāyo. So saṃghạ̣ tāsạ̣ sambahulānaṃ āpattīnạ̣ pațicchannānañ ca, apațicchannānañ ca, chārattạ̣ mānattạ̣ yācati. Saṃgho itthannāmassa bhikkhuno tāsam sambahulānam āpattīnam paṭicchannānañ ca, apațicchannānañ ca, chārattạ̣ mānattam deti. Yassāyasmato khamati itthannāmassa bhikkhuno tāsaṃ sambahulānam āpattīnam pațicchannānañ ca, apațicchannānañ ca, chārattạ̣ mānattassa dānạ̣, so tụ̣hassa, yassa na kkhamati, so bhāseyya. Tatiyam pi etam atthạ̣ vadāmi.

Suṇātu me bhante Sạ̣gho. Ayạ̣ itthannāmo bhikkhu sambahulā samghādisesā āpattiyo āpajji. Āpattipariyantam na jānāti, rattipariyantạ̣ na jānāti. Āpattipariyantạ na sarati, rattipariyantạ na sarati. Āpattipariyante vematiko, rattipariyante vematiko. So sạ̣ghaṃ tāsạ̣ āpattīnạ̣ suddhantaparivāsam yāci. Saṃgho itthannāmassa bhikkhuno tāsaṃ āpattīnaṃ suddhantaparivāsạ̣ adāsi. So parivutthaparivāso ayam itthannāmo bhikkhu sambahulā sạ̣ghādisesā āpattiyo āpajji. Apațicchannāyo. So saṃghạ tāsạ̣ sambahulānam āpattīnạ̣ pațicchannānañ ca apațicchannānañ ca, chārattạ̣ mānattạ̣ yāei. Saṃgho itthannāmassa bhikkhuno tāsạ̣ sambahulānaṃ āpattīnam pațicchannānañ ca, apaṭicchannạ̄nāñ ca, chārattạ̣ mānattạ̣ deti. Yassāyasmato khamati itthannāmassa bhikkhuno tāsạ̣ sambahulānạ̣ 
āpattīnaṃ pațicchannānañ ca, apațicchannānañ ca, chārattạ̣ mānattassa dānam, so tuṇhassa, yassa na kkhamati, so bhāseyya. Dinnam saṃghena itthannāmassa bhikkhuno tasam sambahulānam ạpattīnạ̣ pațicchannānañ ca, apațicchannānañ ca, chārattạ mānattam. Khamati saṃghassa tasmā tuṇhī, evam etạ̣ dhārayāmi.

Ahạ̣ bhante sambahulā sạ̣ghādisesā āpattiyo āpajjị̣. $\bar{A}$ pattipariyantạ̣ na jānāmi, rattipariyantạ̣ na jānāmi. Āpattipariyantạ̣ na sarāmi, rattipariyantạ̣ na sarāmi. $\bar{A}$ pattipariyante vematiko, rattipariyante vematiko. So 'ham bhante sạ̣gham tāsam āpattīnam suddhantaparivāsam yācim, tassa me samgho tāsam ạ âttīnam suddhantaparivāsam adāsi. So 'ham bhante parivutthaparivāso, aham bhante sambahulā saṃghādisesā āpattiyo āpajjiṃ. A pațicchannāyo. So 'ham bhante samgham tāsam sambahulānam āpattinam pațicchannānañ ca, apațicchannānañ ca, chārattạ̣ mānattạ̣ yãcim. Tassa me saṃgho tāsam sambahulānam āpattīnam paticchannānañ ca, apaṭicchannānañ ca, chārattạ̣ mānattạ̣ adāsi. So 'ham bhante mānattam charāmi evadiyām' aham bhante evadiyatîtimạ̣ Samgho dhāretu. Vattạ̣ nikkhippāmi. Mā nikkhippämi.

\section{The Mänatta Discipline.}

Venerable Sirs, I have been guilty of many Samghādisesā offences, but I am ignorant alike of the degree of the offences and of the duration of the times. I can recollect neither, and am, indeed, uncertain as to both. On account of these offences I asked the Samgha for a probation of Complete Purification, and the Samgha gave it me. After completing this probation I committed numerous unconcealed Samghàdisesa offences, so I ask the Samgha, on account of these many offences, to impose upon me the Mānatta penalty.

Let the venerable assembly hear me! A certain Bhikkhu committed many Samghādisesā offences, but being ignorant, uncertain, and unmindful alike of the degree of the offences and of the duration of the times, he asked the Samgha, on account of such offences, to impose upon him a probation 
of Complete Purification. The Samgha accordingly imposed upon him such probation. Since completing this probation this Bhikkhu has been guilty of many Samghādisesã offences which he has not hidden. So he asks the Samgha, on account of the many offences, both hidden and unhidden, to impose upon him the Manatta penalty. If the Samgha is ready, let it impose upon the said Bhikkhu, on account of the said hidden and unhidden offences, the said penance.

This is the motion.

Venerable Sirs, may the Brotherhood hear me!

A certain Bhikkhu has been guilty of many Samghādisesā offences, but he is unaware of the degree of the offences and of the duration of the times. He recollects neither, and is, in fact, uncertain as to both. He asked and obtained from the Samgha a probation of complete purification on account of these offences. Since completing this probation he has committed numerous like offences which he has not concealed, so he asks the Samgha, in respect of such numerous offences, to impose upon him the Mānatta penalty. The Brotherhood accordingly gives him such penalty. Whoever is in favour of the motion, let him be silent; whosoever does not approve, let him speak. I say it thrice.

Let the venerable assembly hear me! A certain Bhikkhu has been guilty of many Samghādisesā offences; but being ignorant, unmindful, and uncertain alike as to the degree of the offences and as to the duration of the times, he asked of the Sumgha, and duly obtained from it, a probation of Complete Purification. Since completing this probation the said Bhikkhu has been guilty of many open offences, involving temporary separation from the Brotherhood. On account of these many open and hidden offences he asked the Samgha for the Mānatta penalty. The Samgha accordingly gives the said Bhikkhu the said penalty. Whosoever is in favour of the motion, let him be silent; on the contrary, let him speak.

The Manatta penalty has been imposed upon the said Bhikkhu by the Samgha on account of these numerous offences, concealed and unconcealed. By its silence the Samgha approves; thus I understand it. 
Venerable Sirs, I have been guilty of many Samghādisesā offences; but being ignorant, unmindful aud uncertain alike of the degree of the offences and of the duration of the times, I asked the Samgha for a probation of Complete Purification on account of these offences, and my request was granted. After undergoing that probation I committed numerous open Samghădisesā offences; so I asked the Samgha, on account of the said many offences, open and hidden, for the Mānatta penalty. My request was granted. Let, therefore, the Samgha understand, that I will fully undergo the said penance.

I keep it, yea, I keep it!

\section{Abbhäna Kammarācā.}

Ahạ̣ bhante sambahulā sạ̣ghādisesā āpattiyo āpajjị̣. Āpattipariyantạ̣ na jānāmi, rattipariyantạ̣ na jānāmi. Āpattipariyantạ̣̄ na sarāmi, rattipariyantạ̣ na sarāmi. Ãpattipariyante vematiko, rattipariyante vematiko. So 'ham bhante saṃgham tāsam ạpattīnaṃ suddhantaparivāsaṃ yāciṃ. Tassa me sạ̣gho tāsam ạ âttīnam suddhan taparivāsạ̣ adāsi. So 'ham 'bhante parivutthaparivãso, ahạ̣ bhante sambahulā saṃghädisesā āpattiyo āpajjị̣. A pațicchannāyo. So 'hạ bhante samghạ̣ tāsam sambahulẩnam āpattīnam pațicchannānañ ca, apațicchannānañ ca chārattạn mānattām yāciṃ. Tassa me saṃgho tāsạ̣ sambahulānam āpattīnạ̣ pațicchannānañ ca, apațicchannānañ ca chārattam mānattạm adāsi. So 'hạ̣ bhante ciṇnamānatto sạ̣gham abbhānaṃ yācāmi.

Suñātu me bhante Saṃgho. Ayam itthannāmo bhikkhu sambahulā saṃghādisesã āpattiyo āpajji. Āpattipariyantam na jānāti, rattipariyantạ na jānāti. Āpattipariyantạ̣ na sarati, rattipariyantam na sarati. Āpattipariyante vematiko, rattipariyante vematiko. So samgham tạsam āpattinam suddhantaparivāsam yāci. Saṃgho itthannāmassa bhikkhuno tāsam āpattīnam suddhantaparivāsam adāsi. So parivutthaparivāso ayạ̣ itthannāmo bhikkhu sambahulā sạ̣ghādisesā āpattiyo āpajji. Apațicchannāyo. So saṃghạ̣ tāsam sam- 
bahulānam āpattīnam pațicchannānañ ca, apațicchannānañ ca, chārattam mānattạ̣ yāei. Samgho itthannāmassa bhikkhuno tāsạ̣ sambahulānam ạ attīnam paṭicchannānañ ca, apațicchannānañ ca chārattam mānattam ciṇnamānatto saṃgham abbhānam yācati. Yadi saṃghassa pattakallam saṃgha itthannāmạ̣ bhikkhum abbheyya.

Esā ñatti.

Suṇātu me bhante saṃgho. Ayạ̣ itthannāmo bhikkkhu sambahulā samghhādisesā āpattiyo āpajji. Āpattipariyantam na jānāti, rattipariyantam na jānāti. Āpattipariyantạ na sarati, rattipariyantam na sarati. $\bar{A}$ pattipariyante vematiko, rattipariyante vematiko. Saṃghạ̣ tāsạ̣ āpattīnam suddhantaparivāsam yāei. Samgho itthannāmassa bhikkhuno tāsam āpattīnạ̣ suddhantaparivāsaụ adāsi. So parivutthaparivāso ayạ̣ itthannāmo bhikkhu sambahulā sạ̣ghādisesā āpattiyo āpajji. Apaticchannāyo. So samgham tāsam sambahulānam āpattīnạ̣ pațicchannānañ ca, apațicchannānañ ca, chārattạ̣ mānattam yāei. Saṃgho itthannāmassa bhikkhuno tāsam sambahulānam āpattīnạ pațicchannānañ ca, apațicchannānañ ca, chārattam mānattạ̣ adāsi. So ciṇnamānatto saṃgham abbhānam yācati. Samgho itthannāmạ̣ bhikkhum abbheti. Yassāyasmato khamati itthannāmassa bhikkhuno abbbānam, so tuṇhassa, yassa na kkhamati, so bhāseyya. Dutiyam pi etam atthạ vadāmi.

Suṇātu me bhante samgho. Ayam itthannāmo bhikkhu sambahulā samghādisesā āpattiyo āpajji. Āpattipariyantạ na jānāti, rattipariyantam na jānāti. Āpattipariyantạ na sarati, rattipariyantam na sarati. Āpattipariyante vematiko, rattipariyante vematiko. So saṃgham tāsạ̣ āpattīnam suddhantaparivāsaṃ yāci. Saṃgho itthannāmassa bhikkhuno tāsam āpattīnam suddhantaparivāsạ̣ adāsi. So parivutthaparivāso ayam itthannāmo bhikkhu sambahulā sạ̣ghādisesā āpattiyo āpajji. Apațicchannāyo. So saṃgham tāsam sambahulānam āpattīnam pațicchannãnañ ca, apațicchannānañ ca, chārattam mānattam yāei. Saṃgho itthannāmassa bhikkhuno tāsam sambahulānam āpattīnam pațicchannānañ ca, apațicchannānañ ca, chārattạ̣ mānattam adāsi. So ciṇnamănatto samgham abbhānam yācati. Saṃgho itthannā- 
mạ̣ bhikkhum abbheti. Yassāyasmato khamati itthannāmassa bhikkhuno abbhānạ̣, so tuṇhassa, yassa na kkhamati, so bhāseyya. Tatiyam pi etam atthạ vadāmi.

Sunātu me bhante sạ̣gho. Ayạ itthannāmo bhikkhu sambahulā saṃghādisesā āpattiyo āpajji. Āpattipariyantạ̣ na jānāti, rattipariyantạ na jānāti. Āpattipariyantam na sarati, rattipariyantam na sarati. A pattipariyante vematiko, rattipariyante vematiko. So saṃghạ̣ tāsam āpattīnạ̣ suddhantaparivāsam yāci. Samgho itthannāmassa bbikkhuno tāsạ̣ āpattīnam suddhantaparivāsam adāsi. So parivutthaparivāso ayạ̣ itthannāmo bhikkhu sambahulā saṃghādisesā āpattiyo āpajji. Apațicchannāyo. So samgham tāsam sambahulānạ̣ āpattīnam pațicchannānañ ca, apațicchannānañ ca chārattạ̣ mānattạ̣ yāci. Saṃgho itthannãmassa bhikkhuno tāsam sambahulānam āpattīnam pațicchannānañ ca, apaṭicchannānañ ca chārattạ̣ mānattạ̣ adāsi. So ciṇnamānatto saṃghạ̣ abbhānaṃ yācati. Saṃgho itthannāmaṃ bhikkhụ̣ abbheti. Yassāyasmato khamati itthannāmassa bhikkhuno abbhānaṃ, so tụ̣hassa; yassa na kkhamati, so bhāseyya. Abbhito samghena ayạ̣ itthannāmo bhikkhu; khamati saṃghassa tasmā tụ̣hī ; evam etạ̣ dhārayāmi. Parisuddho ahạ bhante. Parisuddhạ̣ sīlam me parisuddhetimạ̣ saṃgho dhāretu.

Abbhāna-kammạ̣ samatạ̣ paripuñ̃̃aṃ niṭthitạ̣.

\section{The Act of Rehabilitation.}

Venerable Sirs; having been guilty of many offences involving temporary separation from the Brotherhood, and having been ignorant, unmindful and uncertain alike of the degree of the offences and of the duration of the times, I asked the Samgha for a probation of complete purification on account of such offences, and my request was granted. After undergoing this probation, Venerable Sirs, I committed many open Samghādisesā offences; so I asked the Samgha to impose upon me, on account of these numerous open and hidden offences, the Mānatta penalty, and my request was granted. Having been subjected to that discipline, I now ask for rehabilitation. 
Let the venerable assembly hear me! A certain Bhikkhu having been guilty of numerous Samghädisesa offences, and having been ignorant, unmindful, and uncertain alike as to the degree of the offences and as to the duration of the times, asked the Samgha for a probation of complete purification, and his request was granted. After undergoing such probation the said Bhikkhu committed many open Samghādisesa offences, so he asked the Samgha on account of the numerous open and hidden offences to put him under the Mānatta discipline. His request was granted, and now, having accomplished that penance, he asks the Samgha for rehabilitation. If it seem meet to the Samgha, let it rehabilitate the said Bhikkhu.

This is the proposal.

Venerable Sirs, let the Brotherhood hear me! A certain Bhikkhu having been guilty of many Saṃghādisesa offences, and having been ignorant, unmindful, and uncertain alike as to the degree of the offences and as to the duration of the times, asked the Samgha for a probation of complete purification, and his request was granted. Since undergoing that probation the said Bhikkhu has been guilty of many Samghādisesa offences, some of which he has hidden, others he has not hidden. For this cause he asked the Samgha for the Mānatta discipline, and his request was granted. Having now accomplished that discipline, he asks the Samgha for rehabilitation. The Samgha accordingly rehabilitates the said Bhikkhu. Whosoever approves of the proposal, let him be silent; whoso is not in favour of it, let him speak. I say the same thing twice.

(Repeated) . . . . I say the same thing for the third time.

(Repeated down to "speak"). The said Bhikkhu is rehabilitated by the Samgha. By its silence the Samgha approves; thus I understand it.

Venerable Sirs, I am pure. Let the Samgha believe me to be pure and my character purified!

The complete purificatory Act of Rehabilitation is ended. 
Ten lacquered Talipat leaves, five lines each side, in Burmese characters, constitute the third MS. It deals with probation, penance and rehabilitation, specifying the number of days the offences have been concealed.

\section{Samodhānaparivāsa.}

Namo tassa bhagavato arahato sammāsambuddhassa!

Suñātu me bhante Saṃgho. Ayam itthannāmo bhikkhu sambahulā saṃghādisesā āpattiyo āpajji. Sambahulā āpattiyo ekāhapațicchannāyo. Sambahulā āpattiyo dasāhapațicchannāyo. So saṃgham tāsaṃ āpattīnaṇ yā āpattiyo dasāhapaticchannāyo tāsam agghena samodhānaparivāsạ̣ yācati. Yadi samghassa pattakallạ̣ saṃgho itthannāmassa bhikkhuno tāsam āpattīnạ̣ yā āpattiyo dasāhapaṭicchannāyo tāsaṃ agghena samodhānaparivāsaṃ dadeyya.

Esā ñatti.

Suṇātu me bhante Saṃgho. Ayam itthannāmo bhikkhu sambahulā sạ̣ghādisesā āpattiyo āpajji. Sambahulā āpattiyo ekāhapațicchannāyo. Sambahulā āpattiyo dasāhapațicchannāyo. So samgham tāsam āpattīnam yā āpattiyo dasāhapaṭicchannāyo tāsạ̣ agghena samodhānaparivāsam yācati. Samgho itthannāmassa bhikkhuno tāsaṃ āpattīnam yā āpattiyo dasāhapațicchannāyo tạsam agghena samodhānaparivāsam deti. Yassāyasmato khamati itthannāmassa bhi-

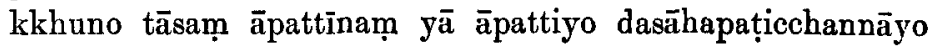
tāsam agghena samodhānaparivāsassa dānam, so tụ̣hassa, yassa na kkhamati, so bhāseyya. Dutiyam pi etam atthạ vadāmi. Tatiyam pi etam attham vadāmi. Dinno samghena itthannāmassa bhikkhuno tāsam āpattīnạ̣ yā āpattiyo dasāhapaticchannāyo tāsạ̣ agghena samodhānaparivāso. Khamati samghassa tasmā tụ̣hī ; evam etạ̣ dhārayāmîti.

Suñātu me bhante saṃgho. Ayam itthannāmo bhikkhu sambahulā sạ̣ghādisesā āpattiyo āpajji. Sambahulā āpattiyo ekāhapaticchannāyo. Sambahulā āpattiyo dasāhapaticchannāyo. So samgham tāsam àpattīnam yā āpattiyo dasāha- 
paticchannāyo tāsạ̣ agghena samodhānaparivāsam yāci. Samgho itthamāmassa bhikkhuno tāsaṃ āpattīnam yā āpattiyo dasāhapaṭicchannāyo tāsạ̣ agghena sumodhānaparivāsam adāsi. So parivutthaparivaso ayạ̣ ithannāmo bhikkhu sambahulā sạ̣ghādisesā āpattiyo āpajji. Apațicchannāyo. So samgham tāsam āpattīnam paṭicchannānañ ca, apaticchannānañ ca, chārattạ̣ mānattạ̣ yācati. Yadi sạ̣ghassa pattakallaṃ saṃgho itthannāmassa bhikkhuno tāsaṃ sambahulānaṃ āpattīnạ̣ pațicchannānañ ca, apaṭicchannānañ ca, chārattạ̣ mānattạ̣ dadeyya.

Esā ñatti.

Sunātu me bhante saṃgho. Ayam itthannāmo bhikkhu sambahulā saṃghādisesā āpattiyo āpajji. Sambahulā āpattiyo ekāhapațicchannāyo. Sambahulā āpattiyo dasāhapațicchannāyo. So saṃghạ̣ tāsam āpattīnạ̣ yā āpattiyo dasāhapațicchannāyo tāsạ̣ agghena samodhānaparivāsạ̣ yāci. Saṃgho itthannāmassa bhikkhuno tāsam āpattīnạ̣ yā āpattiyo dasāhapaticchannāyo tãsam agghena samodhānaparivāsạ̣ adāsi. So parivutthaparivāso ayạ̣ itthannāmo bhikkhu sambahulā sạ̣ghādisesā āpattiyo āpajji. Apațicchannāyo. So saṃghạ̣ tāsạ̣ sambahulānạ̣ āpattīnạ̣ paticchannānañ ca, apaticchannānañ ca chārattạ̣ mānattạ̣ yācati. Saṃgho itthannāmassa bhikkhuno tāsam sambahulānạ̣ āpattīnạ̣ pațicchannānañ ca, apațicchannānañ ca chārattạ̣ mānattam deti. Yassāyasmato khamati itthannāmassa bhikkhuno tāsạ̣ sambahulānam āpattīnạ̣ paṭicchannānañ ca, apaṭicchannānañ ca chārattạ̣ mānattassa dānạ̣, so tuṇhassa, yassa na kkhamati, so bhāseyya. Dutiyam etam atthạ̣ vadāmi. Dinno saṃghena itthannämassa bhikkhuno tāsam sambahulānam āpattīnam paṭicchannānañ ca, apaṭicchannānañ ca chārattạn mānattạ̣. Khamati saṃhassa tasmā tụ̣hī ; evam etạ̣ dhārayāmîti.

Suṇātu me bhante sạ̣gho. Ayam itthannāmo bhikkhu sambahulā saṃghādisesā āpattiyo āpajji. Sambahulā āpattiyo ekāhapațicchannāyo. Sambahulā āpattiyo dasāhapațicchannāyo. So saṃghạ tāsam āpattīnam yā āpattiyo dasāhapatịcchannāyo tāsam agghena samodhānaparivāsạ̣ yāci. Samgho itthannāmassa bhikkhuno tāsaṃ āpattīnam yā 
āpattiyo dasāhapaṭicchannāyo tāsạ̣ agghena samodhānaparivāsam adāsi. So parivutthaparivāso ayam itthannāmo bhikkhu sambahulā saṃhāidisesā āpattiyo āpajji. Apațicchannāyo. So saṃghạ̣ tāsam sambahulānam āpattīnạ̣ pațicchannānañ ca, apaṭicchannānañ ca chārattum mānattạ̣ yāci. Saṃgho itthannāmassa blikkhuno tāsaṃ sambahulānạ̣ āpattīnæm paṭicchannānañ ca, apațicchannānañ ca chārattạ̣ mānattạ̣ adāsi. So ciṇnamānatto sạ̣ghạ̣ abbhānạ̣ yācati. Yadi saṃghassa pattakallạ̣ saṃgho itthannāmạ̣ bhikkhuṃ abbheyya.

Esā ñatti.

Suṇātu me bhante saṃgho. Ayam itthannāmo bhikkhu sambahulā samghādisesā āpattiyo āpajji. Sambahulā āpattiyo ekāhapațicchannāyo. Sambahulā āpattiyo dasāhapațicchanāyo: tāsạ̣ agghena samodhānaparivāsaṃ yāci. Saṃgho itthannāmassa bhikkhuno tāsạ̣ āpattīnạ̣ yā āpattiyo dasāhapațicchannāyo tāsạ̣ agghena samodhānaparivāsạ̣ adāsi. So parivuthaparivāso ayạ̣ itthannāmo bhikkhu sambahulā samghādisesā āpattiyo āpajji : apaticchannāyo. So saṃghạ̣ tāsam sambahulānam āpattīnam pațichannānañ ca, apaṭicchannānañ ca chārattạ̣ mānattạ̣ yāci. Saṃgho itthannāmassa bhikkhuno tāsạ̣ sambahulānam āpattinnạ̣ paticchannānañ ca, apațicchannänañ ca chārattạ̣ mānattạ̣ adāsi. So ciṇnamānatto sạ̣gham abbhānạ̣ yācati. Saṃgho itthannāmạ̣ bhikkhum abbheti. Yassāyasmato khamati itthannāmassa bhikkhuno abbhānam, so tụ̣hassa, ya na kkhamati, so bhāseyya.

Dutiyam pi etam attham vadāmi. Tatiyam pi etam attham vadāmi. Abbhito saṃghena itthannāmo bhikkhu : khamati saṃghassa tasmā tụ̣hī ; evam etạ̣ dhārayāmîti.

Parivāsạ̣ sammādiyāmi. Vattạ̣ sammādiyāmi. Dutiyam pi, tatiyam pi sunkrimvrat. Parivāsam nikkhippāmi. Vattạ̣ nikkhippāmi. Dutiyam pi, tatiyam pi sunkrimvrat. Mānattạ̣ sammādiyāmi. Vattạ̣ sammādiyāmi. Dutiyam pi, tatiyam pi sunkrimvrat. Mānattạ nikkhippāmi, vattạ̣ nikkhippāmi. Dutiyam pi, tatiyam pi sunkrimvrat. Iminā puñ̃̃a kammena bhavā bhave amitta so 'gam labbhanti te. Labbhitvā na varam.

Nibbānam pāpuṇhi! 
The Act of the Chapter.

Probation and Penance.

Praise be to the blessed One, the holy One, to him who has arrived at the knowledge of all Truth !

Venerable Sirs, let the Brotherhood hear me! A certain Bhikkhu has committed numerous offences involving temporary separation from the Samgha, some of which he has concealed for one day and others for ten days. So he asks the Samgha for an inclusive probation on account of the offences which he has concealed for ten days. If it seem meet to the Samgha, let it impose upon him an inclusive probation on account of the offences which he has hidden for ten days.

This is the motion.

Let the Venerable Assembly hear me! A certain Bhikkhu has been guilty of many Samghädisesa offences. Several he has hidden for one day, several for ten days; and he asks the Samgha for an inclusive probation on account of the offences which he has hidden for ten days. The Brotherhood imposes upon this Bhikkhu an inclusive probation on account of the offences which he has hidden for ten days. Whosoever is in favour of granting an inclusive probation to this Bhikkhu on account of the offences which have been hidden for ten days, let him be silent; on the contrary, let him speak! I say it twice. I say it thrice.

On account of the offences which he has concealed for ten days, the Samgha has imposed upon the said Bhikkhu an inclusive probation. By its silence the Samgha approves. Thus I understand it.

Reverend Sirs, may the Samgha hear me! A certain Bhikkhu has been guilty of many Saṃghādisesa offences, some of which he has hidden for one day and others for ten days. On account of those concealed for ten days he asked 
the Samgha for an inclusive probation, and the Samgha imposed upon him such probation. Since undergoing this probation he has committed numerous offences, involving temporary separation from the Brotherhood, which he has not concealed. $\mathrm{He}_{e}$ therefore asks the Samgha for the Manatta penalty in respect of the offences which he has hidden and has not hidden. If the Samgha is ready, let it impose upon the said Bhikkhu, in respect of the many offences hidden and not hidden, the Mãnatta penalty.

This is the motion.

Let the Venerable Assembly hear me ! A certain Bhikkhu has committed numerous Samghādisesa offences, and has concealed many for one day, many for ten days. He asked the Brotherhood for an inclusive probation on account of the offences which he had concealed for ten days, and the Samgha accordingly imposed upon him such probation. After completing this probation the said Bhikkhu was guilty of many Samghädisesa offences which he did not conceal, and he now asks the Samgha for the Mānatta discipline in respect of the many open and hidden offences. The Samgha accordingly imposes upon the said Bhikkhu on account of those numerous hidden and unconcealed offences the Mānatta penalty. Whosoever is in favour of the motion, let him be silent; on the contrary, let him speak! I say the same thing twice.

In respect of the numerous offences, concealed and unconcealed, the Samgha has imposed upon this Bhikkhu the Mānatta penalty. By its silence the Samgha approves. Thus I understand.

Reverend Sirs, let the Assembly hear me! A certain Bhikkhu having been guilty of numerous Samghādisesa offences, many of which he hid for one day, many for ten days, asked the Samgha, on account of the offences which he concealed for ten days, for an inclusive probation, and his request was granted. After undergoing that probation the said Bhikkhu committed numerous Samghādisesa offences which he did not hide; so he asked the Samgha, on account of the many offences hidden and unhidden, for the Mānatta discipline, and his request was granted. Having fulfilled 
that penance, he now asks the Samgha for rehabilitation. If the Samgha is ready, let it rehabilitate the said Bhikkhu.

This is the motion.

Let the Venerable Assembly hear me! Having been guilty of many Samghādisesa offences, several of which he concealed for one day and several for ten days, a certain Bhikkhu asked the Samgha for an inclusive probation, and the Assembly granted such probation in respect of the offences he had hidden for ten days. After undergoing that probation he was guilty of many Samghādisesa offences which he did not hide; so he asked the Samgha, on account of the many open and hidden offences, to impose upon him the Mānatta penalty, and his request was granted. Having completed that penance, he now asks the Samgha for rehabilitation. The Samgha accordingly rehabilitates the said Bhikkhu.

Whosoever is in favour of rehabilitating the said Bhikkhu, let him be silent; on the contrary, let him speak! I say the same thing twice, nay, thrice.

The said Bhikkhu is rehabilitated by the Samgha. By its silence the Samgha approves; thus I understand.

I appreciate the probation, yea, I appreciate it. [To be repeated a second and a third time.] I keep the probation, yea, I keep it. To be repeated twice, nay, thrice. I appreciate the penance, yea, I appreciate it. To be repeated twice, nay, thrice. I keep the penance, yea, I keep it. To be repeated twice, nay, thrice. By this Act the evil nature departs and the good survives; having thus received (rehabilitation), attain nothing better than Nirvāna!

A noteworthy fact about this Manuscript is the sudden appearance of a Burmese word in the Pāli text. Sunkrimvrat seems. to be equivalent to vattabbo.

With the exception of the Bhikkhu's first confession, the next MS. is almost identical with the preceding. It is written on eleven leaves of lacquered royal pasohs, in letters of the tamarind-seed form. 


\section{Samodhänaparizãsa.}

Namo tassa bhagavato arahato sammāsambuddhassa!

Aham bhante sambahulā saṃghādisesā āpattiyo āpajjim. Sambahulā āpattiyo ekāhapaticchannāyo. Sambahulā āpattiyo dvīhapațicchannāyo. Sambahulā āpattiyo tỉhapațicchannāyo. Sambahulā āpattiyo catūhapațicchannāyo. Sambahulā āpattiyo pañcāhapațicchannāyo. Sambahulā apattiyo chāhapațicchannāyo. Sambahulā äpattiyo sattāhapațicchannāyo. Sambahulā āpattiyo atțhāhapațicchannāyo. Sambahulā āpattiyo navāhapațicchannāyo. Sambahulā āpattiyo dasāhapațicchannāyo. So 'ham bhante samgham tāsam ạpattīnam yà àpattiyo dasāhapațicchannāyo tāsam agghena samodhānaparivāsạ̣ yācāmi. Tikkhattum yācitabbo.

(Then follows the Kammavācā as in the preceding MS.)

Venerable Sirs, I have been guilty of numerous offences involving temporary separation from the Brotherhood. Many I have hidden for one day, many for two days, several for three days, several for four days, many for five days, many for six days, several for seven days, several for eight days, many for nine days and many for ten days. So I ask, reverend Sirs, the Samgha to impose upon me, on account of the offences which I have hidden for ten days, an Inclusive Probation.

To be asked three times.

In the first two Kammavāaas the question is only put once (nattidutiya), but in those of Probation and Penance it is always put thrice (ñatticatutthā). The latter form is also used in those Acts of the Chapter which deal with the minor disciplinary proceedings, namely :-

(a) Tajjaniya Kamma (Act of Rebuke).

$(\beta)$ Nissaya Kamma (Act of Subordination).

( $\gamma$ ) Pabbajjaniya Kamma (Act of Banishment).

(8) Pațisāraniya Kamma (Act of Reconciliation).

(є) Ukkhepaniya Kammas (Acts of Suspension). 
By the publication of the above Kammavācās may I venture to hope that, the wish expressed by the learned Translators of the Vinaya Texts, ${ }^{1}$ Dr. Rhys Davids and Dr. Oldenberg, has been, to some extent at all events, fulfilled?

I Sacred Books of the East, vol. xlii. p. xx. 